Nodvin, S.C., H. Van Miegroet, S.E. Lindberg, N.S. Nicholas, and D.W. Johnson. 1995. Acidic deposition, ecosystem processes, and nitrogen saturation in a high elevation Southern Appalachian Watershed. Water, Air and Soil Pollution 85: 1647-1652.

\title{
ACIDIC DEPOSITION, ECOSYSTEM PROCESSES, AND NITROGEN SATURATION IN A HIGH ELEVATION SOUTHERN APPALACHIAN WATERSHED
}

\author{
S.C. Nodvin, H. Van Miegroet, S.E. Lindberg ${ }^{3}$, N.S. Nicholas ${ }^{4}$, and D.W. Johnson \\ ${ }^{1}$ National Biological Service and Graduate Faculty of Ecology and Evolutionary Biology (GFEBB), The \\ University of Tennessee, Knoxville, Tennessee 37996-1610 USA, Internet: nodvin@utk.edu ${ }^{2}$ Forest \\ Resources Department, Utah State University, Logan, UT 84322-2455. USA. ${ }^{3}$ Graduate Faculty in \\ Ecology GFEBB and Environmental Sciences Division, Oak Ridge National Laboratory, Oak Ridge, TN, \\ 37831, USA. ${ }^{4}$ Tennessee Valley Authority, Norris, TN 37828-2001, USA. ${ }^{5}$ Desert Research Institute, \\ University of Nevada, Reno, NV 89506. USA.
}

\begin{abstract}
High-elevation red spruce-Fraser fir forests in the Southern Appalachian mountains: 1) receive among the highest rates of atmospheric deposition measured in North America, 2) contain old-growth forests, 3) have shown declines in forest health, 4) have sustained high insect-caused fir mortality, and 5) contain poorly buffered soils and stream systems. High rates of nitrogen and sulphur deposition ( 1900 and $\sim 2200 \mathrm{Eq}^{-1} \mathrm{hr}^{-1} \mathrm{yr}^{-1}$, respectively) are dominated by dry and cloud deposition processes. Large leaching fluxes of nitrate-nitrogen (100-1400 $\left.\mathrm{Eq}^{\cdot} \mathrm{ha}^{-1} \mathrm{yr}^{-1}\right)$ occur within the soil profile. We have expanded the study to the watershed scale with monitoring of: precipitation, throughfall, stream hydrology, and stream chemistry. Two streamlets drain the 17.4 ha Noland Divide Watershed (1676-1920m) located in the Great Smoky Mountains National Park. A network of $5020 \times 20 \mathrm{~m}$ plots is being used to assess stand structure, biomass, and soil nutrient pools. Nitrate is the predominant anion in the streamlets (weighted concentrations: 47 and $54 \mu \mathrm{eq} \cdot \mathrm{L}^{-1} \mathrm{NO}_{3}{ }^{-} ; 31$ and $43 \mu \mathrm{eq} \cdot \mathrm{L}^{-1} \mathrm{SO}_{4}{ }^{2-}$ ). Watershed nitrate export is extremely high $\left(\sim 1000 \mathrm{Eq}^{\circ} \mathrm{ha}^{-1} \mathrm{yr}^{-1}\right)$, facilitating significant base cation exports. Stream acid neutralizing capacity values are extremely low ( -10 to $20 \mu \mathrm{eq} \cdot \mathrm{L}^{-1}$ ) and episodic acidifications ( $\mathrm{pH}$ declines of a full unit in days

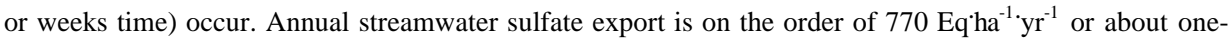
third of total annual inputs, indicating there is net watershed sulfate retention. The system is highly nitrogen saturated (Stage 2, Stoddard, 1994) and this condition promotes both chronic and episodic stream acidification.
\end{abstract}

Key Words: atmospheric deposition, nitrogen saturation, budgets, calcium export, sulphate adsorption

\section{Introduction}

The Southern Appalachian spruce-fir (SASF) ecosystem, located in the eastern United States, is primarily old-growth and $60 \%$ has never been cut or burnedPyle and Schafale, 1988; Dull et al., 1988). However, even the remaining old-growth areas are undergoing severe Fraser fir (Abies fraseri (Pursh) Poir.) mortality due to an infestation by the balsam woolly adelgid (Adelges piceae Ratz.). The exotic insect was first detected in the southern Appalachians in the late 1950's \$peers, 1958). Dendroecological and plot-based data, respectively, have shown red spruce Ricea rubens Sarg.) radial growth decline (LeBlanc et al., 1992) and canopy crown deterioration during the mid- to late 1980's (Peart et al., 1992).

In the 1980's, the Integrated Forest Study (IFS) and related studies demonstrated that high-elevation SASF ecosystems receive among the highest loadings ofulphur (S) and nitrogen $(\mathrm{N})$ measured in North America (Johnson and Lindberg, 1992; total N loadings: $\sim 1900 \mathrm{Eq}^{-1} \mathrm{er}^{-1}$; total S loadings: $2200 \mathrm{Eqha}^{-1 .} \mathrm{yr}^{-1}$ ). Total atmospheric loadings are dominated $(\sim 75 \%)$ by dry and cloud deposition processes. The IFS also found large soil leaching fluxes of nitrate-N (1100-1400 $\left.\mathrm{Eq}^{\cdot} \mathrm{ha}^{-1} \mathrm{yr}^{-1}\right)$. 
We have expanded the stand-based IFS work in the SASF zone to the catchment scale through continued monitoring of: precipitation and throughfall (Shubzdret al., this volume) and additional monitoring of stream hydrology, stream chemistry, and biomass and nutrient distributions. We have monitored water chemistry and hydrology of the two streamlets draining the 17.4 ha Noland Divide Watershed (NDW) since July 1991. In addition, we established a network of $5020 \times 20 \mathrm{~m}$ plots within the watershed to assess stand structure, biomass, and soil nutrient pools (Pauleyet al., submitted). We report here findings for the first three water-years stream-water chemistry trends and $\mathrm{N}, \mathrm{S}$, and calcium (Ca) budgets for the NDW.

\section{Materials and Methods}

\subsection{STUDY AREA}

NDW ( $\left.35^{\circ} 34^{\prime} \mathrm{N}, 83^{\circ} 28^{\prime} \mathrm{W}\right)$ is located between 1676 and $1920 \mathrm{~m}$ within the Great Smoky Mountains National Park, on the North Carolina and Tennessee border. Overstory vegetation of is dominated by red spruce and interspersed patches of standing dead Fraser fir. Yellow birch (Betula alleghaniensis Britt.) serves as a co-dominant in the lower elevations of the watershed. Within the last decade, much of the mature Fraser fir in NDW suffered mortality due to the balsam woolly adelgid infestation (Pauley et al., submitted). The understory consists of regenerating spruce and fir saplings mixed with blackberry Rubus canadensis L.), hobblebush (Viburnum alnifolium Marsh.), mountain-ash (Sorbus americana Marsh.), and various mosses and ferns.

The watershed is underlain by the Thunderhead Sandstone of the Great Smoky Group (Upper Proterozoic), composed principally of quartz and potassic feldspar (Kingt al., 1968). The soils are primarily shallow Inceptisols formed from the bedrock or colluvium, in the upper and lower parts of the watershed (Johnsonet al., 1991).

\subsection{WATERSHED MONITORING}

Five monitoring stations are maintained at NDW: two atmospheric deposition stations at 1740 and $1920 \mathrm{~m}$ (established 1986 and 1993, respectively), a soil solution collection system at $1740 \mathrm{~m}$ (soil depths of 10,20 and $50 \mathrm{~cm}$ ), and two stream monitoring sites (monitoring discharge continuously with $\mathrm{H}$-flumes mounted to the bedrock and weekly chemistry by manual collection) at eachstreamlet draining NDW. Each deposition monitoring station contains two subsites: 1 an "open site", for wet-only deposition, and 2) a throughfall site (Shubzda et al., this volume).

All water samples are analyzed for $\mathrm{pH}$, conductance, major cations and anions (ion chromatography), acid neutralizing capacity (ANC - Gran titration), silica and aluminum (colorimetric) at the Environmental Sciences Laboratory at The University of Tennessee. Methodology for collecting wet deposition, throughfall, and soil solution chemistry follow protocols developed for the IFS (Lindberget al., 1989) and for collecting stream water samples, measuring hydrology, performing water chemistry analyses, and for maintaining Quality Assurance/Quality Control procedures are detailed elsewhere (Nodvin et al., submitted). Nutrient and water budgets for NDW are based upon water years from 1 August through 31 July. 


\subsection{WATERSHED AREA and TOPOGRAPHY}

A high-resolution survey of the watershed topography was completed to 1yletermine watershed area, 2) determine area-elevation relationships (hypsography), and 3establish an accurate reference coordinate system for the watershed. In November 1992, six highly accurate Global Positioning System (GPS) survey units were stationed within or near the NDW for an eight hour period. High resolution aerial stereo photographs were taken less than a week after the GPS data were collected and were georectified using flagged locations of the ground survey points. Using the stereo photographs, UTM and elevational coordinates were determined manually at visible ground at approximately 30 $\mathrm{m}$ distances throughout and surrounding the watershed.

\section{Results and Discussion}

\subsection{STREAM TRENDS}

Nitrate was the predominant anion in NDW streamwaters during most of the study period (Figure 1). Concentrations ranged between 40-80 $\mu \mathrm{eq} \cdot \mathrm{L}$ and showed some seasonal variation with maximum values tending to occur in the winter. Sulphate concentrations were surprisingly low $\left(\sim 20-60 \mu \mathrm{eq} \cdot \mathrm{L}^{1}\right)$ given the large loadings of $\mathrm{S}$

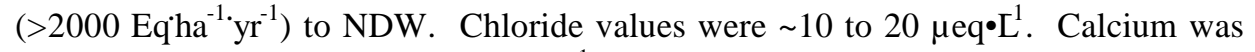
the predominant cation $\left(\sim 40-80 \mu \mathrm{eq} \cdot \mathrm{L}^{-1}\right)$, with magnesium and sodium in the $20-30$ $\mu \mathrm{eq} \cdot \mathrm{L}^{-1}$ range, potassium $\sim 10 \mu \mathrm{eq} \cdot \mathrm{L}^{-1}$, and only trace amounts of ammonium. Streamwater $\mathrm{Ca}$ concentrations and annual exports increased over the study period. Streamwater chemistries at NDW are consistent in what we have found in other streams in the Great Smoky Mountains spruce-fir zone (Flum and Nodvin, this volume).

NDW streams were very poorly buffered $\left(\mathrm{pH}<6\right.$ and ANC $\left.<40 \mu \mathrm{eq} \cdot \mathrm{L}^{1}\right)$ and showed seasonal variation with $\mathrm{pH}$ and ANC values tending to be highest in summer (Figure 1). The streams were susceptible to episodic acidification. For example, in late November and early December 1991, two 18-20 cm storms, resulted pH declines up to one unit and the near or complete consumption of ANC in the streamlets.

\subsection{NUTRIENT BUDGETS}

Sulphate flux in throughfall can be utilized as a good estimator of total S deposition (Lindberg and Lovett, 1992) while $\mathrm{N}$ flux in throughfall is a poor indicator of total $\mathrm{N}$ deposition due to uptake of $\mathrm{N}$ in the forest canopy (Lovett and Lindberg, 1993; Shubzda et al., this volume), and $\mathrm{Ca}$ flux in throughfall is a poor indicator of total $\mathrm{Ca}$ deposition due to net leaching from the vegetation (Johnson and Lindberg, 1992).

$\mathrm{S}$ throughfall fluxes at $1740 \mathrm{~m}$ were consistent with IFS total deposition estimates of $\sim 2200 \mathrm{Eq}^{-1} \mathrm{ha}^{-1 .} \mathrm{yr}^{-1}$ (Table 1). However, S throughfall flux at $1920 \mathrm{~m}$ was much greater ( $3500 \mathrm{Eq}^{-1} \mathrm{ha}^{-1} \mathrm{yr}^{-1}$; see Shubzda et al. this volume). With watershed S exports at $\sim 800$, NDW is retaining between 1400 and $2700 \mathrm{E} \not h a^{-1} \mathrm{yr}^{-1}$. NDW showed a net retention of $\mathrm{N}$, given total (IFS) $\mathrm{N}$ loadings of $\sim 1900$ and an enormous annual stream $\mathrm{N}$ export of $\sim 1090 \mathrm{Eqha}^{-1} \mathrm{yr}^{-1}$. Ca export ( 1300) was a major counter balance to strong acid anion losses. NDW showed net losses of calcium of $\sim 200-300 \mathrm{Eq}^{\cdot} \mathrm{ha}^{-1} \mathrm{yr}^{-1}$.

\subsection{NITROGEN SATURATION IN NDW}

Nitrogen saturation occurs when $\mathrm{N}$ inputs to a system are in excess of the $\mathrm{N}$ retention capacity of that system (Aberet al., 1989). A result can be $\mathrm{NO}_{3}{ }^{-}$export to 
Table 1. Water (cm) and Ion $\left(E q \cdot h a^{-1} y^{-1}\right)$ Fluxes from the NDW by water-year

\begin{tabular}{|c|c|c|c|c|}
\hline Water-Year & Water & Ca & N & S \\
\hline & \multicolumn{5}{|c|}{ Wet Deposition 1740 m } \\
\hline $1991-92$ & 219 & 81 & 511 & 719 \\
\hline $1992-93$ & 233 & 57 & 348 & 525 \\
\hline $1993-94$ & 295 & 85 & 477 & 739 \\
\hline & \multicolumn{5}{|c|}{ Throughfall flux 1740 m } \\
\hline $1991-92$ & 210 & 695 & 677 & 1927 \\
\hline $1992-93$ & 236 & 637 & 729 & 2174 \\
\hline $1993-94$ & 286 & 908 & 1535 & 2479 \\
\hline & \multicolumn{5}{|c|}{ Watershed Export (Both streamlets) } \\
\hline $1991-92$ & 207 & 1088 & 1005 & 805 \\
\hline $1992-93$ & 210 & 1164 & 1052 & 772 \\
\hline $1993-94$ & 253 & 1626 & 1218 & 960 \\
\hline
\end{tabular}

stream water. In an $\mathrm{N}$ saturated system nitrate may be an equal or greater agent of soil and water acidification than sulfate and may play a critical role in episodic acidification of streams (Kahl et al., 1992; Murdoch and Stoddard, 1992; Wigington et al., 1993).

$\mathrm{N}$ saturation stages can be delineated based on the magnitude and temporal variability of biological retention (e.g. plant uptake and microbial immobilization) relative to $\mathrm{N}$ inputs (from the atmosphere or mineralization). Stoddard (1994) developed a ranking system for $\mathrm{N}$ saturation based upon annual $\mathrm{N}$ budgets and seasonal streamwater nitrate trends. A stage 0 system is N-deficient, showing little or no NQ loss regardless of the levels of input $\mathrm{N}$. With increasing $\mathrm{N}$ loading, stage 1 can occur whereby N@̄ peaks appear in stream water during the winter dormant period while low values persist when vegetation is active. Further $\mathrm{N}$ input leads to stage 2, marked by declining $\mathrm{N}$ retention and elevated $\mathrm{NO}_{3}{ }^{-}$concentrations in streams throughout the year. Stage 3 is reached when the terrestrial system becomes a net source of $\mathrm{N}^{2} \mathrm{NQ}{ }^{-}$to the aquatic system as outputs exceed inputs and biological control on streamwater NQ- concentration is essentially absent (Aberet al., 1989; Stoddard, 1994).

NDW is Stage 2 nitrogen saturated, contributing to both chronic and episodic streamwater acidification and net catchment export of $\mathrm{Ca}$. Episodes of accelerated nitrification in NDW soils have resulted in the elevation of soil solution aluminum concentrations to values known to cause inhibition of calcium uptake in red spruce (Johnson et al., 1991). Nutritional concerns in red spruce in NDW could be associated with high $\mathrm{NO}_{3}{ }^{-}$leaching rates (Van Miegroetet al., 1993).

When catchment nitrification rates were accelerated, as a result of disturbance (Nodvin et al., 1988) or enhanced $\mathrm{N}$ loadings (Moldan et al., 1995), the resultant soil acidification enhanced catchment $S$ retention through enhanced sulphate adsorption. Therefore reduced sulphate export in NDW may, in fact, be a function of $\mathrm{N}$ saturation status. Were it not for the significant catchment retention of sulphate, thereby reducing the total export of acidic anions, chronic and episodic streamwater acidification and $\mathrm{Ca}$ export would be even greater than what we are currently observing in NDW. 

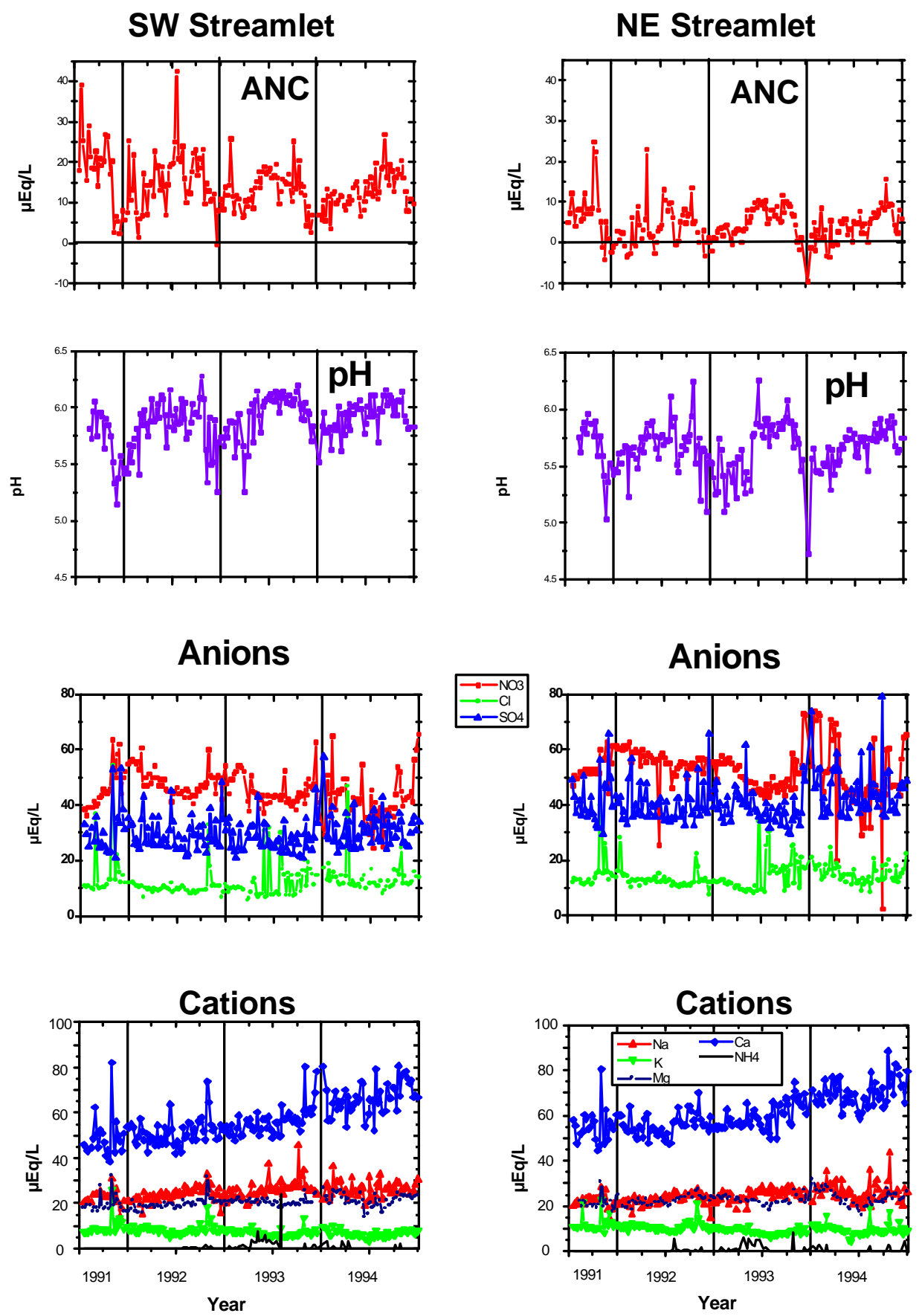

Figure 1. Water Chemistry Trends in NDW Streams from July 1991 through December 1994 


\section{Acknowledgments}

This is a contribution of the Great Smoky Mountains National Park Long-Term Inventory and Monitoring Program and was funded by the USDI National Park Service and National Biological Service. Special thanks to the staffs of the UT CPSU and the Great Smoky Mountains NP, Ellen Williams, and Matt Malick.

\section{References}

Aber, J.D., Nadeihoffer, K.J.,. Steudler, P, \& ,Melillo J.M.: 1989, Bioscience 39, 378-386.

Flum, T. and Nodvin, S.C.: 1995, Water, Air and Soil Pollution this volume.

Dull, C.W., Ward, J.D., Brown, H.D., Ryan, G.W., Clerke, W.H., and Uhler, R.J.: 1988, USDA Forest Service, Southern Region Protection Report R8-PR 13.

Johnson, D.W. and Lindberg, S.E.: 1992, "Atmospheric deposition and forest nutrient cycling", Springer-Verlag, New York.

Johnson, D.W., Van Miegroet, H., Lindberg, S.E., Todd, D.E., and Harrison, R.B.: 1991, Canadian Journal of Forest Research 21, 769-787.

Kahl, J.S., Norton, S.A.,. Haines, T.A,. Rochette, E.A, Heath, R.H. and. Nodvin, S.C.: 1992, Environmental Pollution 78, 37-44.

King, P.B., Neuman, R.B., and Hadley, J.B.: 1968, Geological Survey Professional Paper \#587, Washington D.C.

LeBlanc, D. C.,. Nicholas, N. S, andZedaker, S. M.: 1992, Canadian Journal of Forest Research 22, 905-914.

Lindberg, S.E., Johnson, D.W.: Lovett, G.M., Taylor, G.E., Van Miegroet, H., and Owens, J.G. 1989, ORNL/TM11214, Oak Ridge National Laboratory, Oak Ridge, TN..

Lindberg, S.E., and Lovett, G.M.: 1992,Atmospheric Environment 26A, 1477-1492.

Lovett, G.M. and Lindberg, S.E.: 1993, Canadian Journal of Forest Research 23, 1603-1616.

Moldan, F., Hultberg, H., Nyström, U. and Wright, R.F.: 1995, Forest Ecology and Management 71, 89-97.

Murdoch, P.S. and Stoddard, J.L.: 1992, Water Resources Research 28, 2707-2720.

Nodvin, S.C., Driscoll, C.T., \& Likens, G.E.: 1988Biogeochemistry 5, 185-199.

Nodvin, S.C., Flum, T., Shubzda, J., Rhodes, H., Malick, M., Williams, E., Van Miegroet, H., Lindberg, S.E., Pauley, E.F., Rose, A.K., and Nicholas, N.S.: 1995 (submitted), "A comprehensive water quality monitoring program for the Great Smoky Mountains National Park", Technical Report Series, National Biological Service, WashingtonD.C.

Pauley, E.F., Nodvin, S.C., Nicholas, N.S., Rose, A.K., and Coffey, T.B.: 1995 (submitted). Bulletin of the Torrey Botanical Club.

Peart, D.R., Nicholas, N.S., Zedaker, S.M., Miller-Weeks, M.M., and Siccama, T.G.: 1992, In: Eagar, C. and Adams M.B. (eds.) The ecology and decline of red spruce in the eastern United States. Springer-Verlag, New York.

Pyle, C.and Schafale, M.P.: 1988,Journal of Forest History 53(3), 183-193.

Shubzda, J., Lindberg, S.E., Garten, C.T., and Nodvin, S.C.: 1995, Water, Air and Soil Pollution this volume.

Speers, C. F.: 1958, Journal of Forestry 56, 515-516.

Stoddard, J.L.: 1994, In: Environmental chemistry of lakes and reservoirs L.A. Baker (ed), Advances in Chemistry Series No. 237, American Chemical Society, pp. 223-284.

Van Miegroet, H., Johnson, D.W., and Todd,D.E.: 1993, Canadian Journal of Forest Research $\mathbf{2 3}, 89-95$.

Wigington, P.J. Jr., Baker, J.P., DeWalle, D.R., Krester, W.A., Murdoch, P.S., Simonin, H.A., Van Sickle, J., McDowell, M.K.,. Peck, D.V, and Barchet, W.R.: 1993, EPA/600/R-63/190, U.S. Environmental Protection Agency, Corvallis, OR. 337p. 